\title{
EFFECT OF DIFFERENT APPLIED POTASSIUM SOURCES ON QUANTITY AND QUALITY OF GROUNDNUT CROP GROWN UNDER NEWLY RECLAIMED SANDY SOIL CONDITIONS
}

\author{
Mohamed S. Awaad, Azza R. Ahmed and Abdalla A.M. Mohamedin
}

Soils, Water and Environment Res. Inst., Agric. Res. Center, Giza, Egypt

\begin{abstract}
:
A field experiment was conducted on a newly reclaimed sandy soil at the Experimental Farm of Ismaellia Agriculture Research Station during a summer season of 2009 to study the effect of applied potassium sulfate, as a mineral fertilizer, alone and its integrated with different Ksources, i.e., vinasse (by-product of sugarcane complementary industries) and wood ashes on groundnut yield and its components, i.e., chemical constituents (i.e., macro and micro nutrients uptake by both hays and seeds) and biochemical ones (i.e., seed protein, oil and its components of fatty acids). The effect of different applied K-sources on some soil properties was taken into consideration in the current study.

The obtained results show that application of the tested K-sources led to a significant increase for each of the studied plant parameters (i.e., weight of 100 seed in $\mathrm{g}$, weight of pods in $\mathrm{kg} \mathrm{fed}^{-1}$, hay and seed yields in $\mathrm{kg} \mathrm{fed}^{-1}$ ), chemical constituents (i.e., macro and micro nutrients uptake by both hays and seeds) and biochemical ones (i.e., seed protein, oil and its components of fatty acids). Whilst the application of the tested Ksources had a greater effect on the aforementioned plant parameters, particularly the combined treatments of potassium sulfate integrated with vinasse followed by wood ashes, which were recorded the greatest values, and potassium sulfate fertilizer alone.

As for response of soil properties to the applied treatments, the obtained data reveal that the combined treatments of potassium sulfate integrated with either vinasse or wood ashes resulted in a significant decrease in each of soil $\mathrm{pH}$ and ECe values vs a significant increase in each of soil content of organic matter and available nutrients of $\mathrm{N}, \mathrm{P}$ and $\mathrm{K}$. Thus, it could be recommended that application of potassium sulfate as a mineral fertilizer integrated with either vinasse or wood ashes as combined treatments can be used for maximizing the profitability of potassium sulfate in such newly reclaimed sandy soils, and in turn increasing the yield of groundnut seeds and improving its quality.
\end{abstract}

Key words: Groundnut crop newly reclaimed sandy soils, vinasse, wood ashes, soil properties and K-sources.

\section{INTRODUCTION:}

Potassium is one of sixteen essential nutrients required for plant growth and reproduction, and it is classified as a macronutrient, such as either

Fayoum J. Agric. Res. \& Dev., Vol.24, No.1, January, 2010 
nitrogen or phosphorus (Marschner, 1995). Potassium is not a constituent of any plant structures or compounds. It plays a part in many important regulatory roles in the plant, it is essential in nearly all processes needed to sustain plant growth and reproduction. Also, potassium plays a vital role in; translocation of photosynthesis products, protein synthesis, control of ionic balance, regulation of plant stomata and water use, activation of plant enzymes and many other processes (Krauss and Jiyun, 2000).

Soil is an important factor and foundation for agricultural production. In Egypt, more desert areas either sandy or calcareous in nature have to be put under cultivation. Such soils are poor with respect to their physico-biochemical properties, soil water-plant relationships as well as their nutritional status.

Groundnut (Arachis hypogaea L.) is one of the most important summer legume crops cultivate in sandy soils of Egypt. It is used as whole seed or as food, and the green plants are used as either a high quality for animal feed or a green manure. Being a leguminous crop, it can fix atmospheric nitrogen in soil through root nodule bacteria and thus improves soil fertility. Moreover, groundnut seeds contain about $50 \%$ oil and $22-30 \%$ protein.

The response of different crops to K-fertilizers was evaluated by some researchers, such as Abd El-Hadi et al. (1990) who found that addition of potassium sulfate (SOP) increased the production of most field crops. Faizy (1997) found that the yield and quality of cotton, maize and rice grains increased with the addition of SOP. Under desert conditions, El-Kadi (1997) reported that wheat, corn, and sugar beet responded to $\mathrm{K}$ application. In Teheran, Malakouti (1997) found that the introduction of high yielding varieties potato, sugar cane and sugar beet responded to $\mathrm{K}$ application. Also, Tisdale et al. (2002) showed that K plays an important role in improving the grain protein content of wheat probably by enhancing the $\mathrm{N}$-use efficiency.

Aramrak et al. (2007) reported that groundnut grown on sandy soils, which are mostly deficient in potassium. For correcting such a deficiency, potassium fertilizer was applied to these soils. In recent years, interest in the utilization of organic waste materials as a source of plant nutrients that have markedly increased, due to the high cost of chemical fertilizers and waste disposal problems. Vinasse is a by-product of sugar cane complementary industries, as it is produced from the fermentation of molasses and it can be used as a source of potassium. Gomez and Rodriguez (2000) found that the application of vinasse would substitute for $55 \%$ of $\mathrm{N}, 72 \%$ of $\mathrm{P}_{2} \mathrm{O}_{5}$ and $100 \%$ of the $\mathrm{K}_{2} \mathrm{O}$ required for sugar cane crop in Venzuela. Arafat and Yassen (2002) concluded that application of vinasse increased crop because it is a good source of many of nutrients which plants needed to growth.

Wood ashes are an excellent source of potassium, however, burning of wood drives away all of carbon and leaves an ash that is usually more than 5 $\% \mathrm{~K}_{2} \mathrm{O}$. Priyadharshini and Seran (2009) found that the application of paddy husk ash at the rate of 4.5 tons/ha is suitable for obtaining high yield of

Fayoum J. Agric. Res. \& Dev., Vol.24, No.1, January, 2010 
cowpea in a sandy soil. Mittra et al. (2005) reported that wood ash and fly ash could be used as sources of plant nutrients for crop production.

Hence, this work was carried out at identifying the effect of either vinasse or wood ashes combined with potassium sulfate as a mineral fertilizer versus a potassium sulfate alone, as conventional K-sources on seed quantity or quality, status of some macro and micro nutrients of groundnut crop grown on a newly reclaimed sandy soil as well as their positive effects on some soil properties.

\section{MATERIALS AND METHODS:}

A field experiment was conducted on a newly reclaimed sandy soil at the Experimental Farm of Ismaellia Agriculture Research Station during a summer season of 2009. Some initial physical and chemical characteristics of the studied experimental soil as well as the used vinasse and wood ashes, which were determined according to Black $\boldsymbol{e t}$ al. (1965) and Page $\boldsymbol{e t}$ al. (1982), are presented in Tables (1 and 2).

Table (1): Some characteristics of the studied experimental soil at initial state.

\begin{tabular}{|c|c|c|c|}
\hline Soil character & Value & Soil character & Value \\
\hline \multirow{2}{*}{$\begin{array}{l}\text { Particle size distribution \%: } \\
\text { Sand }\end{array}$} & \multirow[b]{2}{*}{92.1} & $\mathrm{pH}(1: 2.5$,soil suspension) & 7.70 \\
\hline & & \multicolumn{2}{|c|}{ Chemical analysis of soil paste extract: } \\
\hline Silt & 2.2 & ECe $\left(\mathrm{dS} \mathrm{m}^{-1}\right)$ & 1.55 \\
\hline Clay & 5.7 & \multicolumn{2}{|l|}{ Soluble cations $\left(m_{\text {molc }}^{L-} 1\right)$ : } \\
\hline Textural class & Sandy & \multirow{4}{*}{$\begin{array}{l}\mathrm{Ca}^{++} \\
\mathrm{Mg}^{++} \\
\mathrm{Na}^{+} \\
\mathrm{K}^{+}\end{array}$} & \multirow{2}{*}{$\begin{array}{l}5.50 \\
3.95\end{array}$} \\
\hline $\mathrm{CaCO}_{3}$ content $\%$ & 1.40 & & \\
\hline Organic matter content $\%$ & 0.08 & & 6.10 \\
\hline Available $\mathrm{N} \quad\left(\mathrm{mg} \mathrm{kg}^{-1}\right)$ & 11.7 & & 0.45 \\
\hline Available $\mathrm{P} \quad\left(\mathrm{mg} \mathrm{kg}^{-1}\right)$ & 2.81 & \multicolumn{2}{|l|}{ Soluble cations ( $m$ molc $\left.{ }^{L-} 1\right)$ : } \\
\hline Available $\mathrm{K} \quad\left(\mathrm{mg} \mathrm{kg}^{-1}\right)$ & 40.00 & \multirow{3}{*}{$\begin{array}{l}\mathrm{CO}_{3}^{--} \\
\mathrm{HCO}_{3}^{-} \\
\mathrm{Cl}^{-}\end{array}$} & 0.00 \\
\hline Available Fe $\left(\mathrm{mg} \mathrm{kg}^{-1}\right)$ & 3.60 & & 2.40 \\
\hline Available $\mathrm{Mn}\left(\mathrm{mg} \mathrm{kg}^{-1}\right)$ & 0.52 & & 5.20 \\
\hline Available $\mathrm{Zn} \quad\left(\mathrm{mg} \mathrm{kg}^{-1}\right)$ & 0.45 & $\mathrm{SO}_{4}^{--}$ & 8.40 \\
\hline
\end{tabular}

Table (2): Some chemical properties of the vinasse and wood ashes

\begin{tabular}{|l|c|c|}
\hline \multicolumn{1}{|c|}{ Material properties } & Vinasse & Wood ashes \\
\hline $\mathrm{pH}(1: 5$, soil suspension) & 4.11 & 9.43 \\
\hline ECe $\left(\mathrm{dS} \mathrm{m}^{-1}\right.$, water extract 1:5) & 5.30 & 4.20 \\
\hline Organic matter content \% & 46.49 & Nil \\
\hline Total nitrogen \% & 1.41 & 0.05 \\
\hline Total phosphorus \% $\%$ & 0.25 & 0.47 \\
\hline Total potassium \% $\%$ & 1.14 & 7.00 \\
\hline Total calcium $\%$ & 0.89 & 8.50 \\
\hline Total iron $\left(\mathrm{mg} \mathrm{kg}^{-1}\right)$ & 8798 & 4842 \\
\hline Total manganese $\left(\mathrm{m} \mathrm{kg}^{-1}\right)$ & 458 & 356 \\
\hline Total zinc $\left(\mathrm{mg} \mathrm{kg}^{-1}\right)$ & 262 & 125 \\
\hline Total copper $\left(\mathrm{mg} \mathrm{kg}^{-1}\right)$ & 12 & 52 \\
\hline
\end{tabular}

Fayoum J. Agric. Res. \& Dev., Vol.24, No.1, January, 2010 
A randomized complete block design with six treatments and three replicates was carried out. Plot area was $3.0 \times 3.5 \mathrm{~m}$. Vinasse and wood ashes as sources of potassium were applied to soil as basal treatment for K-sources. Treatments in this experiment were as follows:

Treatment symbol

T1

T2

T3

T4

Applied fertilizer fractions

The control treatment.

$60 \mathrm{~kg} \mathrm{~N} / \mathrm{fed}$ as ammonium nitrate $+30 \mathrm{~kg} \mathrm{P}_{2} \mathrm{O}_{5} / \mathrm{fed}$ as calcium super phosphate $+48 \mathrm{~kg} \mathrm{~K}_{2} \mathrm{O} / \mathrm{fed}$ as potassium sulfate.

$60 \mathrm{~kg} \mathrm{~N} / \mathrm{fed}$ as ammonium nitrate+ $30 \mathrm{~kg} \mathrm{P}_{2} \mathrm{O}_{5} / \mathrm{fed}$ as calcium super phosphate $+24 \mathrm{~kg} \mathrm{~K}_{2} \mathrm{O} / \mathrm{fed}$ as potassium sulfate $+24 \mathrm{~kg} \mathrm{~K}_{2} \mathrm{O} / \mathrm{fed}$ as vinasse.

$60 \mathrm{~kg} \mathrm{~N} / \mathrm{fed}$ as ammonium nitrate+ $30 \mathrm{~kg} \mathrm{P}_{2} \mathrm{O}_{5} / \mathrm{fed}$ as calcium super phosphate $+24 \mathrm{~kg} \mathrm{~K}_{2} \mathrm{O} / \mathrm{fed}$ as potassium sulfate $+24 \mathrm{~kg} \mathrm{~K}_{2} \mathrm{O} / \mathrm{fed}$ as wood ashes.

Nitrogen fertilizer was applied in three equal doses, i.e., at sowing, 30 and 60 days from plantation date. Fertilizers of phosphorus as a calcium super phosphate $\left(15 \% \mathrm{P}_{2} \mathrm{O}_{5}\right)$ and potassium sulfate $\left(48 \% \mathrm{~K}_{2} \mathrm{O}\right)$ were added during the seed bed preparation. Also, gypsum at a rate of $500 \mathrm{~kg} / \mathrm{fed}$ was added during the seed bed preparation. Seeds of groundnut (Arachis hypogea, cv. Giza 5) were inoculated just before sowing with the specific rhizobium bacteria inoculants and were sown in hill $10 \mathrm{~cm}$ apart in ridges at a spacing of $60 \times 30 \mathrm{~cm}$. The normal cultural practices for groundnut crop were applied as recommended in the area under consideration. Sprinkler irrigation was applied as plant needed for soil moisture.

At harvest the yield and its components were recorded. All plants of each plot were harvested to determine number of pods as well as hay, pod and seed yields. Also, the nutrient contents of $\mathrm{N}, \mathrm{P}, \mathrm{K}, \mathrm{Fe}, \mathrm{Zn}$ and $\mathrm{Mn}$ uptake by groundnut hays and seeds were determined according to Chapman and Pratt (1978). Crude protein \% was calculated by multiplying $\mathrm{N} \%$ by 6.25 (Deyoe and Shellenberger, 1965). Seed oil content and its component of fatty acids were determined according to A.O.A.C. (1980). The obtained data were subjected to statistical analysis, which were performed by using the MSTAT Statistical Package (1990).

\section{RESULTS AND DISCUSSION:}

\section{Effect of different applied potassium sources on some plant parameters:}

Data in Table (3) presented the effect of different applied potassium sources on some plant parameters at harvest stage of groundnut crop, i.e., 100 seed weight, weight of pods as well as hay and seed yields. Results showed that all the studied parameters were significantly increased by application of the tested different K-sources. Also, the obtained data showed that the application of potassium sulfate fertilizer integrated with either vinasse or wood ashes, particularly as combined treatments, were more significantly effective on the studied plant parameters of groundnut crop at harvest stage. Results also emphasized that the greatest values of 100 seed weight, weight of pods as well as hay and seed yields were recorded with plants received the

Fayoum J. Agric. Res. \& Dev., Vol.24, No.1, January, 2010 
treatment of T4 $\left(24 \mathrm{~kg} \mathrm{~K} 2 \mathrm{O} /\right.$ fed as potassium sulfate $+24 \mathrm{~kg} \mathrm{~K} \mathrm{~K}_{2} \mathrm{O} / \mathrm{fed}$ as wood ashes). However, the lowest values of the corresponding plant parameters were recorded with those fertilized by the treatment of $\mathrm{T} 2\left(48 \mathrm{~kg} \mathrm{~K}_{2} \mathrm{O} / \mathrm{fed}\right.$ potassium sulfate fertilizer alone). The beneficial effects of the combined treatments might be due to the stimulation integration between potassium sulfate fertilizer and either wood ashes or vinasse application on improving the physicochemical properties of the experimental soil, and in turn increasing soil fertility and enhancing the availability of many essential plant nutrients to plant uptake. Such favourable conditions were positively reflected on improving the vegetative growth of groundnut plants as well as increasing the hay and seed yields. Also, this simulative effect may be due to the role of potassium on production of enzyme activity and enhanced translocation of assimilative and photosynthesis (El-Desuki et al., 2006).

Table (3): Effect of different applied potassium sources on some plant parameters at harvest stage of groundnut crop.

\begin{tabular}{|c|c|c|c|c|}
\hline Treatments & $\begin{array}{c}\text { Weight of } \\
\text { 100 seed (g) }\end{array}$ & $\begin{array}{c}\text { Weight of } \\
\text { pods (kg/fed) }\end{array}$ & $\begin{array}{c}\text { Hay yield } \\
\text { (kg/fed) }\end{array}$ & $\begin{array}{c}\text { Seed yield } \\
\text { (kg/fed) }\end{array}$ \\
\hline T1 (Control) & 56.2 & 622.0 & 588.9 & 382.0 \\
\hline T2 & 84.6 & 1288.0 & 1509.0 & 938.0 \\
\hline T3 & 90.3 & 1495.0 & 1610.0 & 1135.0 \\
\hline T4 & 93.8 & 1512.0 & 1771.0 & 1152.0 \\
\hline L.S.D. at 0.05 & 1.43 & 6.69 & 2.27 & 3.11 \\
\hline
\end{tabular}

In addition, these results are in agreement with the findings of Seripong (1988) who concluded that phosphorous and paddy husk ash improved nodulation, yield and some soil properties of Thailand soils. Okon et al. (2005) stated that the optimum level of rice husk ash plus 0.05 ton urea per ha can sustain rapid growth and better yield of okra even faster than NPK, because rice husk ash contains almost all other essential plant nutrients and the presence of nitrogen will boost their uptake. Singh et al. (2002) reported that improved water use efficiency in soil and higher yield of wheat crop can be achieved when soil amended by fly ash. Priyadharshini and Seran (2009) concluded that application of paddy husk ash as a source of potassium at a rate of 4.5 tons/ha are favorable for yield advancements in cowpea.

\section{Chemical constituents of groundnut plants:}

a. Macronutrients of $N, P$ and $K$ uptake by hay and seed yields:

Data in Table (4) showed that the values of macronutrients (N, P and K) uptake by groundnut plant organs, i.e., hays and seed were significantly increased due to the application of different K-sources as compared to the control treatment (T1). The obtained data showed that application of either vinasse or wood ashes combined to potassium sulfate recorded the greatest values of $\mathrm{N}, \mathrm{P}$ and $\mathrm{K}$ uptake by both hays and seeds of groundnut as compared with applied potassium sulfate fertilizer alone.

Fayoum J. Agric. Res. \& Dev., Vol.24, No.1, January, 2010 
Table (4): Effect of different applied potassium sources on $N, P$ and $K$ uptake by hay and seed yields of groundnut crop.

\begin{tabular}{|c|c|c|c|c|c|c|}
\hline \multirow{3}{*}{ Treatments } & \multicolumn{6}{|c|}{ Macronutrients uptake (kg/fed) } \\
\cline { 2 - 7 } & \multicolumn{5}{|c|}{ Hays } & Keeds \\
\cline { 2 - 7 } & $\mathbf{N}$ & $\mathbf{P}$ & $\mathbf{N}$ & $\mathbf{P}$ & $\mathbf{K}$ \\
\hline T1 (Control) & 7.06 & 1.20 & 7.65 & 9.55 & 2.50 & 7.64 \\
\hline T2 & 20.37 & 2.30 & 21.12 & 32.83 & 4.60 & 28.14 \\
\hline T3 & 22.70 & 3.50 & 25.50 & 45.40 & 5.70 & 36.32 \\
\hline T4 & 26.21 & 3.90 & 28.74 & 51.84 & 4.90 & 39.16 \\
\hline L.S.D. at 0.05 & 1.04 & 0.07 & 2.28 & 7.61 & 0.12 & 1.56 \\
\hline
\end{tabular}

Also, data revealed that the combined treatment of $\mathrm{T} 4$ (potassium sulfate + wood ashes) was the most superior one for the nutrients of $\mathrm{N}, \mathrm{P}$ and $\mathrm{K}$ uptake by hays and seeds followed by T3 (potassium sulfate + vinasse), whereas the treatment of $\mathrm{T} 2$ (potassium sulfate individually) was the usefulness one for all $\mathrm{N}, \mathrm{P}$ and $\mathrm{K}$ uptake. These favourable conditions could be explained by a fact that the total amount of $\mathrm{K}$, which added from either vinasse or wood ashes along the growing period, was sufficient to meet the $\mathrm{K}$ required for groundnut plants. A similar finding was obtained by Ayeni (2008) who found that combined of cocoa pod ash and NPK fertilizer increased N, P, K, $\mathrm{Ca}$ and $\mathrm{Mg}$ uptake by tomato plants. Arafat and Yassen (2002) reported that the addition of vinasse increased the uptake of nitrogen, phosphorus and potassium. Wood ash increased the $\mathrm{K}$ concentration in corn and winter wheat (Triticum aestivum L.) in greenhouse studies (Erich, 1991).

b. Micronutrients of Fe, Zn and Mn uptake by hay and seed yields:

Data presented in Table (5) indicated that the application of potassium sulfate alone and its combination with either vinasse or wood ashes increased the values of Fe, $\mathrm{Zn}$ and $\mathrm{Mn}$ uptake by both hay and seed yields of groundnut crop as compared to the control treatment.

Table (5): Effect of different applied potassium sources on Fe, $\mathrm{Zn}$ and $\mathrm{Mn}$ uptake by hay and seed yields of groundnut crop.

\begin{tabular}{|c|c|c|c|c|c|c|}
\hline \multirow{3}{*}{ Treatments } & \multicolumn{5}{|c|}{ Micronutrients uptake (g/fed) } \\
\cline { 2 - 7 } & \multicolumn{3}{|c|}{ Hays } & \multicolumn{3}{c|}{ Seeds } \\
\cline { 2 - 7 } & Fe & Zn & Mn & Fe & Zn & Mn \\
\hline T1 (Control) & 54.40 & 27.20 & 23.60 & 38.00 & 24.20 & 18.00 \\
\hline T2 & 81.90 & 68.00 & 43.00 & 47.00 & 42.10 & 23.99 \\
\hline T3 & 124.20 & 98.40 & 78.54 & 85.00 & 60.76 & 45.67 \\
\hline T4 & 102.00 & 92.80 & 72.40 & 83.23 & 57.59 & 39.79 \\
\hline L.S.D. at 0.05 & 1.68 & 0.08 & 0.06 & 1.83 & 0.26 & 0.09 \\
\hline
\end{tabular}

The greatest values of $\mathrm{Fe}, \mathrm{Zn}$ and Mn uptake by both hays and seed were obtained by application of potassium sulfate combined with vinasse, however, the relative increase percentages reached 128.30 and $123.68 \%$ for $\mathrm{Fe}, 261.76$ and $151.07 \%$ for $\mathrm{Zn}$ and 232.79 and $153.72 \%$ for Mn, respectively, over the control treatment. These results may be due to the application of vinasse

Fayoum J. Agric. Res. \& Dev., Vol.24, No.1, January, 2010 
enhanced some soil chemical properties, and consequently such profitable conditions positively reflected on the micronutrients availability and uptake by plant organs. These obtained data are in harmony with those reported by Bhanooduth (2006) who found that addition of wastes from sugar industry like vinasse or burning of sugar cane bagasse to soil increase availability of $\mathrm{Fe}, \mathrm{Zn}$ and $\mathrm{Mn}$ in the soil.

\section{Oil and protein contents \% of seed groundnut:}

Data in Table (6) show that the oil and protein contents of groundnut seeds were increased under all applied treatments as compared to the control one. The greatest values of both oil and protein contents were obtained by plants received the treatment of T4 $(60 \mathrm{~kg} \mathrm{~N} / \mathrm{fed}$ as ammonium nitrate+ $30 \mathrm{~kg}$ $\mathrm{P}_{2} \mathrm{O}_{5} /$ fed as calcium super phosphate $+24 \mathrm{~kg} \mathrm{~K} 2 \mathrm{O} /$ fed as potassium sulfate + $24 \mathrm{~kg} \mathrm{~K} \mathrm{~K}_{2} \mathrm{O} / \mathrm{fed}$ as wood ashes). These results may be due to the application of potassium enhanced of $\mathrm{N}$-uptake, and consequently improved the protein synthesis. Anuradha and Sharma (1995) found that the application of potassium increased the chlorophyll content, nitrate reductase activity, seed protein and oil content in soybean. Deshmukh $\boldsymbol{e t}$ al. (1994) reported that the highest soybean yield and oil content with an application of $60 \mathrm{~kg} \mathrm{~K} / \mathrm{O} / \mathrm{ha}$ at Amravati and $90 \mathrm{~kg} \mathrm{~K} \mathrm{~K}_{2} \mathrm{O} / \mathrm{ha}$ at Akola in Maharashtra State. Shahid et al. (1999) found that potassium application improved the crop harvest index and grain quality parameters (protein and oil contents) of boldness.

Table (6): Effect of different applied potassium sources on oil and protein contents in seeds of groundnut.

\begin{tabular}{|c|c|c|c|c|}
\hline \multirow{2}{*}{ Treatments } & \multicolumn{2}{|c|}{ Seed content \% } & \multicolumn{2}{c|}{ Seed total yield (kg/fed) } \\
\cline { 2 - 5 } & Oil & Protein & Oil & Protein \\
\hline T1 (Control) & 43.30 & 15.62 & 165.40 & 59.66 \\
\hline T2 & 45.00 & 21.87 & 422.10 & 205.14 \\
\hline T3 & 47.00 & 25.00 & 533.50 & 283.75 \\
\hline T4 & 49.20 & 28.12 & 578.10 & 323.94 \\
\hline L.S.D. at 0.05 & 0.84 & 1.05 & 2.93 & 11.87 \\
\hline
\end{tabular}

Also, Shafeek et al. (2005) reported that potassium plays an important role in many biochemical processes such as photosynthesis, respiration, protein and carbohydrates metabolism.

\section{Fatty acid components of groundnut seed oil:}

Data in Table (7) indicated that application of potassium sulfate alone or combined with either vinasse or wood ashes resulted in a pronounced decrease of total saturated fatty acids (i.e., lauric, myristic, palmitic, stearic, erachidic and behenic) as compared to the control treatment. Contrary, the lowest values of total unsaturated fatty acids were obtained by application of T3 (60 kg $\mathrm{N} / \mathrm{fed}$ as ammonium nitrate $+30 \mathrm{~kg} \mathrm{P}_{2} \mathrm{O}_{5} /$ fed as calcium super phosphate +24 $\mathrm{kg} \mathrm{K} 2 \mathrm{O} /$ fed as potassium sulfate $+24 \mathrm{~kg} \mathrm{~K}_{2} \mathrm{O}$ /fed as vinasse). Regarding the effect of different treatments on unsaturated fatty acids, data showed that all applied treatments caused an increase for the total unsaturated fatty acids as

Fayoum J. Agric. Res. \& Dev., Vol.24, No.1, January, 2010 
compared to the control treatment. Oleic and linoleic were the dominated of the component of unsaturated fatty acids. However, the applied treatments of T3 followed by T4 were recorded the greatest values of unsaturated fatty acids as compared to the potassium sulfate alone. Mekki et al. (1999) stated that application of potassium fertilizer increased the oleic and linoleic component of unsaturated fatty acids of sunflower seeds.

Table (7): Effect of different applied potassium sources on seed oil components of fatty acids.

\begin{tabular}{|c|c|c|c|c|}
\hline \multirow{2}{*}{$\begin{array}{c}\text { Seed oil components (fatty } \\
\text { acids) }\end{array}$} & \multicolumn{4}{|c|}{ Applied treatments } \\
\cline { 2 - 5 } & T1 (Control) & T2 & T3 & T4 \\
\hline Lauria & 6.21 & 3.9 & 0.00 & 1.33 \\
\hline Myristic & 1.25 & 0.9 & 0.80 & 0.31 \\
\hline Palmitic & 4.21 & 7.1 & 5.8 & 3.91 \\
\hline Stearic & 3.65 & 2.5 & 3.6 & 4.25 \\
\hline Arachidic & 3.80 & 1.5 & 1.8 & 2.40 \\
\hline Behenic & 2.54 & 2.4 & 0.1 & 1.54 \\
\hline Total saturated fatty acids & 21.66 & 17.93 & 11.3 & 13.74 \\
\hline Palmitoleic & 2.30 & 1.30 & 1.3 & 1.64 \\
\hline Oleic & 40.54 & 45.25 & 55.2 & 56.32 \\
\hline Linoleic & 24.21 & 23.03 & 27.8 & 27.37 \\
\hline Linolenic & 9.65 & 11.75 & 1.85 & 1.64 \\
\hline Erucoic & 0.98 & 0.98 & 0.88 & 0.25 \\
\hline Total unsaturated fatty acids & 77.68 & 82.31 & 87.76 & 86.97 \\
\hline
\end{tabular}

These results may be due to the beneficial effect of applied of potassium on increasing total unsaturated fatty acids which play an activator of many enzymes processes where some of these enzymes may affect the seed oil components. Zakaria et al. (2005) found that application of potassium caused an increase for seed oil content and total unsaturated fatty acids (oleic and linoleic), while the total saturated fatty acids were decreased.

V. Some soil chemical properties and nutrients status at harvest stage of groundnut crop:

Data presented in Table (8) indicated that application of different treatments caused an alternative pattern for each of the studied soil chemical properties (i.e., $\mathrm{pH}, \mathrm{ECe}$, organic matter content and available nutrients of $\mathrm{N}$, $\mathrm{P}$ and $\mathrm{K}$ ). The obtained results revealed that $\mathrm{pH}$ values at harvest stage of groundnut plants, were more affected due to the different applied treatments. Vinasse combined with potassium sulfate (T3) seemed to be the most pronounced effect on reducing soil $\mathrm{pH}$ values. The reduction in soil $\mathrm{pH}$ value might be attributed to the effect of the applied vinasse, which contains a high amount of active organic acids and its less $\mathrm{pH}$ value (4.11). These results are in accordance with results of Adel and Mohsen (2008) who found that application of vinasse to a newly reclaimed loamy sand soil caused a significant decrease in soil $\mathrm{pH}$. Concerning the soil salinity (ECe), data presented in Table (8) showed a significantly decrease in ECe values of the

Fayoum J. Agric. Res. \& Dev., Vol.24, No.1, January, 2010 
soil paste extract due to application of different treatments. The positive affects of either applied vinasse or wood ashes combined with potassium sulfate may be due to the removed soluble salts that associated with the agricultural management practices.

Table (8: Effect of different applied potassium sources on some soil chemical properties and nutrients status at harvest stage of groundnut crop.

\begin{tabular}{|c|c|c|c|c|c|c|}
\hline \multirow{2}{*}{ Treatment } & \multicolumn{3}{|c|}{ Soil chemical properties } & \multicolumn{3}{c|}{$\begin{array}{c}\text { Available macronutrient } \\
\text { contents (mg/kg) }\end{array}$} \\
\cline { 2 - 7 } & $\begin{array}{c}\mathbf{p H} \\
(\mathbf{1 : 2 . 5})\end{array}$ & $\begin{array}{c}\text { ECe } \\
(\mathbf{d S} / \mathbf{m})\end{array}$ & $\begin{array}{c}\text { Organic } \\
\text { matter\% }\end{array}$ & $\mathbf{N}$ & $\mathbf{P}$ & $\mathbf{K}$ \\
\hline T1 (Control) & 7.5 & 1.15 & 0.10 & 18.21 & 2.52 & 47.00 \\
\hline T2 & 7.2 & 0.83 & 0.14 & 20.25 & 3.14 & 71.05 \\
\hline T3 & 7.1 & 0.92 & 0.21 & 32.21 & 5.68 & 96.00 \\
\hline T4 & 7.3 & 0.95 & 0.13 & 22.31 & 4.12 & 84.70 \\
\hline L.S.D. at 0.05 & 0.18 & 0.15 & 0.03 & 1.18 & 0.35 & 8.08 \\
\hline
\end{tabular}

As for soil organic matter content, data in Table (8) showed that its content tended to significant increased due to the application of the different applied treatments, particularly the treatment of vinasse combined with potassium sulfate. Devarajam et al. (1996) reported that the significant increase in the organic matter content of the soils with vinasse could be attributed to the high organic load of the vinasse. Moreover, data in Table (8) reveal that all the applied treatments could result in higher available $\mathrm{N}, \mathrm{P}$ and $\mathrm{K}$ contents in soil as compared with the control treatment. The treatment of potassium sulfate combined with vinasse caused significant increase in the contents of $\mathrm{N}, \mathrm{P}$ and $\mathrm{K}$ in the experimental soil at the harvest stage of groundnut crop. This finding is more attributed to the higher nutritive value of vinasse. Also, the application of the by-product of vinasse to the soil increased soil microbial biomass and mineralization of its organic matter, and consequently increased $\mathrm{N}-\mathrm{NO}_{3}$ content in the soil. Meena et al. (1986) stated that the vinasse application to soil increased the total $\mathrm{N}$ and organic matter content. Arafat and Yassen (2002) found that the residual available N, P and K and organic matter in soil after wheat harvesting, generally, increased with increasing rates of vinasse applied.

\section{REFERENCES:}

Abd El Hadi, A.H.; Khadr, M.S. and M.A.M. Hassan (1990). Effect of fertilization on the productivity of major crops under intensive cropping system in Egypt. $3^{\text {rd }}$ International Congress Program of Soil Science Society of Pakistan, March 20-22.

Adel, R.A.U. and A.G. Mohsen (2008). Effect of sugar industry wastes on K status and nutrient availability of a newly reclaimed loamy sandy soil. Archives of Agronomy and Soil Sciences, 54: 665-679.

Anuradha, K. and P.S. Sharma, (1995). Effect of moisture stress and applied potassium on yield and biochemical parameters of soybean in Virtisols. Journal of Oilseeds Research, 12 (2): 275-278.

Fayoum J. Agric. Res. \& Dev., Vol.24, No.1, January, 2010 
A.O.A.C. (1980). Association of Official Analytical Chemists, Official Methods of Analysis. $13^{\text {th }}$ Ed., Washington, D.C.

Arafat, S. and A. Yassen (2002). Agronomic evaluation of fertilizing efficiency of vinasse $17^{\text {th }}$ WCSS, 14-12 August 2002, 1991-1998.

Aramrak, S.; J. Chanchareonsook; C. Suwannarat and E. Sarobol (2007). Assessment of multi-element extractants for prediction of available potassium in Thai Soils. Kasetsart J. (Nat. Sci.), 41 (3): 461-466.

Ayeni L.S. (2008). Integrated application of cocoa pod ash and npk fertilizer on soil chemical properties and yield of tomato. American-Eurasian Journal of Sustainable Agriculture, 2 (3): 333-337.

Bhanooduth, L. (2006). The effect of sugar industry wastes on extractable heavy metals in soil. $18^{\text {th }}$ World Congress of Soil Science., July 9-11 2006, Philadalphia Pennesylvania, USA.

Black, C.A.; D.D. Evans; L.E. Ensminger; J.L. White and F.E. Clark (1965). Methods of Soil Analysis. Am. Soc. of Agron. Inc., Madison, Wisconsin, USA.

Chapman, H. D. and R. F. Pratt (1978). Methods Analysis for Soil, Plant and Water. Univ. of California Div. Agric. Sci., pp. 16-38.

Deshmukh, V.N.; R.P. Rangacharya; S.S. Rewatkar and B.U. Solanke (1994). Response of soybean to phosphorus and potassium application in Vertisol. Journal of Potassium Research, 10 (4): 332-337.

Devarajam, L., R. Rajannan and G. Oblisami (1996). Proc. Nat. Symp. On Use of Purification. Canda J. Biochem. Physiol., 37: 911.

Deyoe, C.W. and J.A. Shellenberger (1965). Amino acids and proteins in sorghum grain. J. Agric. and food Chem., 13:446.

El-Desuki M.; M.M. Abdel-Mouty and A.H. Ali (2006). Response of onion plants to additional dose of potassium application. Journal of Applied Science Research, 2 (9): 592-597.

El-Kadi, M. (1997). Response to potassium of some field crops and trees fruit grown in desert soils. Regional workshop of the International Potash Institute, Food security in the WANA region. The essential need for balanced fertilization. Bornova, Izmir, Turkey 26-30 May.

Erich, M. (1991). Agronomic effectiveness of wood ash as a source of phosphorus and potassium. J. Environ. Qual., 20:576-581.

Faizy, S. (1997). Effect of balanced fertilization on yield and crop quality in Egypt. Regional Workshop of the International Potash Institute. Food security in the WANA region. The essential need for balanced fertilization. Bornova, Izmir, Turkey, 26-30 May.

Gomez, J. and O.Rodriguez (2000). Effect of vinasse on sugar cane (Saccharum officinarum) productivity. Rev. Fac. Agron. (CUZ), 17: 318-326.

Krauss, A. and J. Jiyun (2000). Strategies for improving balanced fertilization. International Potash Institute, Basel Switzerland.

Malakouti, M.J. (1997). Potassium status in soils and crops recommendations and present use in Iran. Regional Workshop of the International Potash Institute, Food Security in the WANA region. The essential need for balanced fertilization. Bornova, Izmir, Tukey, 26-30- May.

Fayoum J. Agric. Res. \& Dev., Vol.24, No.1, January, 2010 
Marschner, H. (1995). Mineral Nutrition of Higher Plants. Second Edition, Academic Press London, pp. 889.

Meena, M.A.; C. Martinez and A. Noa (1996). Changes in organic fraction and biological activity. Cien. Agric., 29:122-127.

Mekki, B.B.; M.A. El-Kholy and E.M. Mohamed (1999). Yield, oil and fatty acids content as affected by water deficit and potassium fertilization in two sunflowers cultivars. Egypt J. Agron, 21: 67-85.

Mittra, B.N.; S. Kramkar; D.K. Swain and B.C. Gosh (2005). Fly ash, a potential source of soil amendment and a component of integrated plant nutrient supply system. FUEL, 84: 1447-1451.

MSTAT-C. (1990). Micro Computer Statistical Program for Experimental Design and Analysis. Russell Freed (Ed.), MSTAT/Michigan State University, East Lansing MI.

Ojeniyi S.O.; O.P. Oso; A.A. Arotolu (2002). Response of Vegetables to Wood Ash Fertilizer. Proceeding of $35^{\text {th }}$ Annual Conference of Agricultural Society of Nigeria, pp. 33-39.

Okon P.B.; S.O. Joseph and C.A. Uche (2005). Effect of rice husk ash and phosphorus on some properties of acid sands and yield of Okra. Communications in Soil Science and Plant Analysis, 36 (7): 833-845.

Page, A.I.; R.A. Miller and D.R. Keeney Eds. (1982): Methods of Soil Analysis. Part 2: Chemical and Microbiological Properties. $2 \stackrel{n d}{ }$ Ed., Amer. Soc. of Agron., Madison, Wisconsin, U.S.A.

Priyadharshini, J and T.H. Seran (2009). Paddy husk ash as a source of potassium for growth and yield of cowpea (Vigna unguiculata 1.). The Journal of Agricultural Sciences, 4 (2): 67-76.

Seripong, S. (1988). Responses of cowpea to applications of phosphorus and burned rice husk in an acid soil. Thai Journal of Agricultural Science, 21 (1): 111.

Shafeek, M.R.; O.A.H. Elzeiny and M.E. Ahmed (2005). Effect of natural phosphate and potassium fertilizer on growth, yield and seed composition of pea plant in new reclaimed soil. Asin Journal Plant Sciences, 4 (6): 608-612.

Shahid, U.; S.K. Bansal; P. Imas and H. Magen (1999). Effect of foliar fertilization of potassium on yield, quality, and nutrient uptake of groundnut. Journal of Plant Nutrition, 22: 1785-1795.

Singh, C.B., M.C. Oswal and K.S. Grewal (2002). Impact of fly ash application on consumptive and water use efficiency in wheat (Triticum aestivum) under different soils. Ind. J. Agri. Sci., 72: 396-399.

Tisdale, S.L.; W.L. Nelson; J.D. Beaton and J.L. Havlin (2002). Soil and Fertilizer Potassium. pp. $230-265$, In: Soil Fertility and Fertilizers $\left(5^{\text {th }}\right.$ Ed.), Prentice Hall of India, New Delhi.

Zakaria, M.S.; S.A. Hafez; E.B. Ahmed and A. Abou El-Ela (2005). Cotton seed, protein, oil yield and oil properties as influenced by potassium fertilization and foliar application of zinc and phosphorus. World Journal of Agriculture Sciences, 2 (1): 66-74.

Fayoum J. Agric. Res. \& Dev., Vol.24, No.1, January, 2010 
تأثير إضافة مصادر مختلفة من البوتاسيوم على كمية ونوعية محصول الفول السودانى إنى

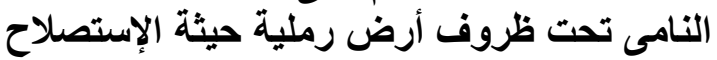

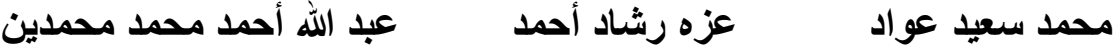

$$
\begin{aligned}
& \text { معهد بحوث الأراضى والمياه والبيئة ـ مركز البحوث الزمد الزراعية ـ جيزة ــ مصر معدين }
\end{aligned}
$$

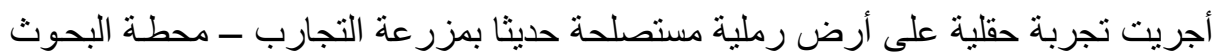

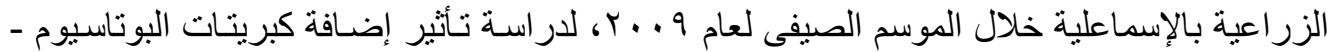

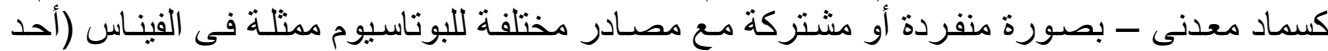

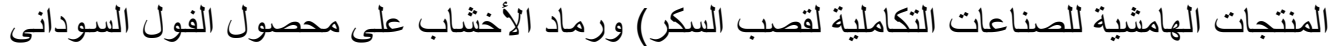

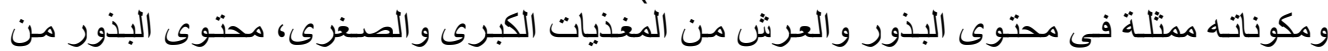

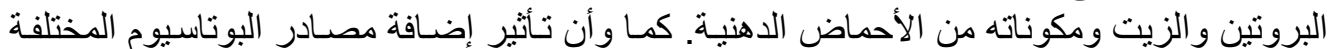

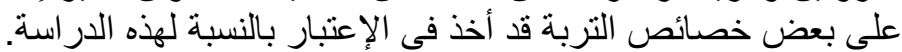

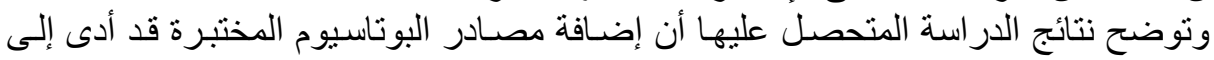

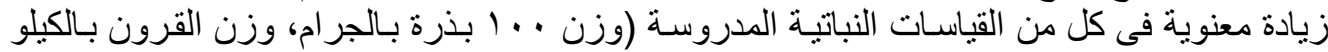

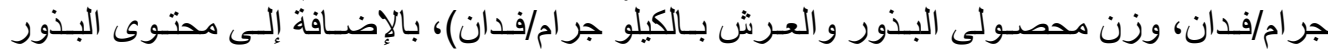

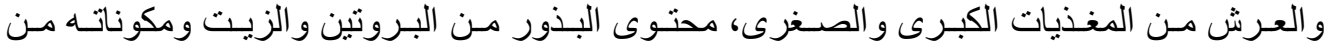

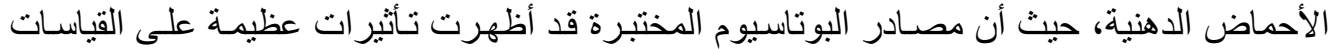

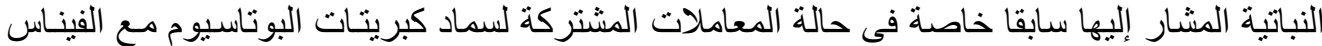

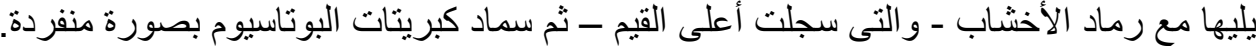

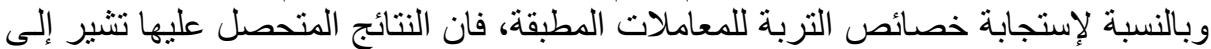

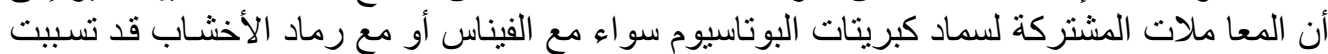

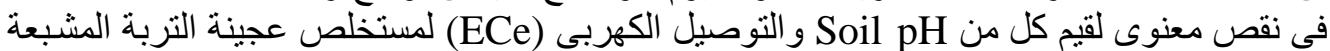

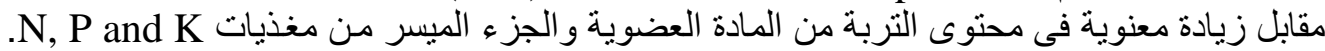

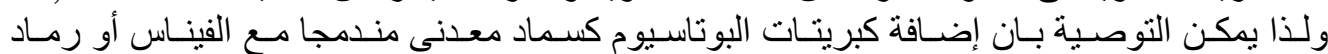

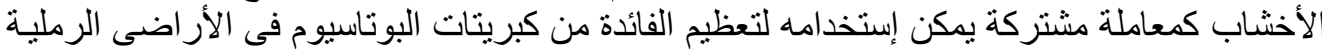

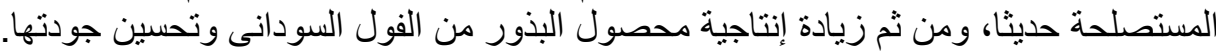

